\title{
Science, Science Literacy and Communication
}

\author{
G S Rautela* and Kanchan Chowdhury**
}

(Received 27 April 2015; revised 16 September 2015)

\begin{abstract}
The article aims to highlight the role of science communication through various channels for fostering scientific literacy and developing scientific temper in the society. In order to articulate the national vision and aspiration in the field of S\&T, the Indian Parliament framed successive Science and Technology Policies keeping in pace with the development of S\&T in global arena and keeping in mind national needs. Guided by such policies, India has made a remarkable progress in S\&T but the extent to which science and scientific knowledge is actually transmitted to the common masses needs to be reassessed. India has a long history of science communication agencies and it has been emphasised in science policy documents framed at various stages where it involved both individuals and institutions. The necessary impact of such approach has been discussed with examples and with a special emphasis on the role of informal science education and communication specially science museums and science centres in communicating science to the common man through various user friendly and participatory methods. Effort has been made to highlight the need for making science communication and education engaging, participatory and contextual with renewed vision and vigour to enable todays' and tomorrows' citizens to play a more active role in the research and innovation process, to make informed choices and to build a democratic and knowledge-based society.
\end{abstract}

Key Words: Cultivation of science, Engagement in science, Interactive exhibits, Innovation, Knowledge creation, Lifelong learning, Outreach, Science centres/museums, Science literacy, Science communication, Science on wheels, Scientific enterprise, Science popularisation, Science and technology, Science, Technology and innovation policy, Scientific temper, Vigyan mandir.

\section{INTRODUCTION}

An integral part of the socio-economic developmental process of a country is science and technology (Ahmed and Stein, 2004, pp.5-24). Its primary objective is to build the understanding, skills and knowledge base of individuals and institutions. The importance of science and technology to modern societies and the role of a scientifically \& technologically literate population in promoting social and economic development has long been recognized. Science and technology communication is broadly understood as the system of measures aimed at the dissemination (Libutti and Valente, 2006, pp.191-197), appropriation and valuing of science and technology goods (Martinez, 1999; Simon, 2009, pp. 89-114) which include critical thought, ideas and values (Burns, O'Connor and Stocklmayer, 2003, pp. 183-202), understandung of history and sociology of scientific knowledge, science \& society interrelationship, understanding and appreciation of how science is practiced and the results of scientific research and technological development are utilized (Miller, 2004, pp.273-294). The communication of science and technology plays a central role in the socioeconomic, cultural, and environmental development of any country

\footnotetext{
* Former Director General, National Council of Science Museums, 1202, Darshan Heights, Balashet Madhurkar Marg, Lower Parel, Mumbai-400013. Email: gangarautela.1979@gmail.com

** Curator, National Council of Science Museums, 33 Block - GN, Sector- V, Bidhan Nagar Kolkata-700091
} 
(Miller, Pardo, and Niwa, 1997; Rogers, 1976, pp.213-240).

In socioeconomic terms, the communication of science and technology makes it possible to develop a scientific culture in the society, develop scientific literacy and motivate talent for scientific research, technological development, and intellectual endeavours in general. It fosters creativity and innovation contributing in the production of better trained human resources, expands social opportunities and strengthens the educational system. Culturally and environmentally, the popularization of science enhances the critical sense of the population, by increasing its involvement in informal decisionmaking and contributing to democratic stability and sustainable development.

It has been a continuous national endeavour, both by the governmental and the non-governmental organizations, to infuse scientific temper in the society, thereby building a scientifically and technologically literate nation with logically thinking people. Various agents are involved in popularizing science, each with different roles and functions.

India decided, after independence, to make science and technology an integral part of its development strategy. The Indian Parliament endorsed a Scientific Policy Resolution, as early as in 1958, articulating the vision and aspiration of the nation. Engagement of the common man with S\&T was considered a necessary part of this strategy. The S\&T communication, popularisation and fostering of a scientific temper among the masses and decision makers has been emphasised again and again through the successive policy instruments promulgated during 1958, 1983, 2003 and 2013. Each document has amply emphasised the importance of science popularisation. Government and non-governmental organisations have played and are still playing a vital role in fostering the scientific temper in the country.

\section{Science And Technology In India}

In India, the lines dividing science and technology have, traditionally, been drawn very sharply though it is changing but slowly. Even at the level of governmental policy statements, the divide is emphasized by the existence of two distinct enunciations of national intent the Science Policy Resolution of 1958 and the Technology Policy Statement of 1983.

India's Scientific Policy Resolution (SPR) of 1958, a pace setter in the world, remains valid even today. The SPR resolved to "foster, promote and sustain" the "cultivation of science and scientific research in all its aspects". Technology was then assumed to flow from the country's established science infrastructure. The SPR also emphasized the use of the scientific approach in all activities of the nation. The Technology Policy Statement (TPS) of 1983, enunciated at the time of constraints on import of technology, emphasized the need to attain technological competence and self-reliance. Several of its statements were converted into action. The Science and Technology Policy (STP) of 2003 brought science and technology (S\&T) together. It emphasized the need for investment into $R \& D$ to address national problems. It called for integrating programmes of socioeconomic sectors with the national R\&D system. The Science, Technology \& Innovation Policy 2013 articulated the need for innovation and creation of a national innovation eco-system (Science, Technology and Innovation Policy, 2013).

Today innovation is no longer a mere appendage to science and technology but has assumed centre stage in the developmental goals of countries around the world. Vertical integration of all dimensions of STI into the socio-economic processes seems the way forward in the modern world. New paradigms of innovation have emerged and systems that foster innovation are not 
universal. They have become country and context specific. The Prime Minister of India, at the Indian Science Congress-2010 declared 2010-20 as the "Decade of Innovations" and formed the National Innovation Council. The STI Policy 2013 is in furtherance of the declaration to develop synergy between STI that aims to bring fresh perspectives to bear on innovation in the changing context. The policy thus seeks to focus on both people for science and science for people and combine the benefits of excellence and relevance.

There is a fairly widespread perception that basic science done in India is not relevant for technology. Here knowledge creation was considered more important than its practical application for social welfare or wealth generation. However, the history of Indian science shows that this perception is not always true. For example in 1895, Jagadish Chandra Bose used what are today known as microwaves to ignite gunpowder and ring a bell at some distance - without the aid of any mechanical or electrical contact. But he too did not convert that knowledge into a practical application i.e. mobile telephony. Raman spectroscopy is beginning to be used for wide spread applications that directly affect the common man's life and many such examples can be cited from other fields. What all of them show is that the journey from idea to product is complex, and demands identification science and technology developed in a variety of other fields for quite different applications, and a variety of expertise all the way from science to technology and then to manufacturing, financing and marketing and a whole new ecosystem that encourages innovation. It needs a culture, a mind-set, skill to always think of application of knowledge created to develop products, processes or output that drive economy and used for social benefit (Science in India, 2004-2013) .

India has made a remarkable progress in science and technology in the past three decades.
India's resources and strengths in science are considerable, but the potential to apply it for wealth generation \& social benefit is still far from satisfactory realization. The rapid economic growth of the last fifteen years makes it feasible for the country to invest a great deal more in science than it could do earlier. Contribution to Research \& Development ( R \& D) from private sources is on the increase even though it still remains relatively small.

However, to what extent the science and scientific knowledge is actually transmitted to the common masses remains a concern? Similar is the situation with adoption of newer technologies in manufacturing, traditional crafts for better productivity \& quality improvement. Several programmes and initiatives have been launched to promote science and communicate science by bridging the gap between new knowledge in science and technology and common masses through diffusion of information. The primary concern is to help science and scientific culture penetrate India's diverse society, and to transform it into a nation of scientifically thinking and scientifically aware people. Public perception of Science \& Technology is not always positive. Many still consider science as incomprehensible \& technology frightening. A section of society considers it anti-human. Science communication, being a complex network of social channels, serves as a mechanism for bridging the gap between the scientific community and the lay public. It is also an effective tool for enhancing public understanding, appreciation and engagement and gaining wide public support for important research and development, which are indispensable for society's development. Moreover, there are multiple challenges in the way science is communicated in a culturally diverse and complex social environment. It is even more difficult to increase scientific literacy as a society where obscurantism \& superstitions are believed in as a routine. 


\section{SCience Literacy}

There are insufficient, and not always effective, opportunities for leaders, social groups, and the general public to participate together in making strategic S\&T choices and to take advantage of scientific expertise in order to understand certain crucial issues with broad-ranging social consequences: the location of nuclear power plants and the disposal of nuclear wastes, blood contaminated with the HIV virus, planting or use of transgenic plants as food and, more generally, recombinant DNA field tests, genetic testing, cloning, the uses of information technologies, etc. Moreover, the general population's technical culture appears very inadequate. This is particularly serious among young people, those who will need to work in economies that will be strongly - and increasingly - affected by rapid technical change. If public interest in science and technology is to be improved, the main effort must be put for science literacy. Successive science policies of the Government have put enough emphasis on communication of science through, science museums, planetariums etc. The recognition of non-formal mode of science communication, simply because of its effectiveness, is a key recommendation (Rennie and Williams, 2002, pp.706-726) .

Science literacy is an urgent and important issue and is rapidly becoming one of the great issues in our life since all our activity is being touched by products or processes of S\&T

(Jack and Rannikmae, 2009, pp.275288). The issue of science literacy has its roots in centuries-old debates about public education. It is a general belief that if one cannot read, write or add, he's not likely to know much science. According to Jon Miller, Director of the Public Opinion Laboratory at Northern Illinois University, "Scientific Literacy is one of those terms that is often used but seldom defined. The scientifically literate should understand the scientific method and vocabulary well enough to follow public debates about issues involving science and technology (Norris \& Phillips, 2003, pp.224-240).

An influential concept of science literacy includes four elements: (a) knowledge of basic facts of science, (b) an understanding of methods of science i.e. keen observations, questioning, reasoning, experimental design, drawing conclusions and understanding (c) an appreciation of the positive outcomes of science and technology, (d) the rejection of unfounded beliefs and obscurantism. Science literacy with its ability to follow scientific discourse can connect the world of science to the context of everyday life and make science personally relevant. By keeping these overlapping yet distinct vantage points clearly in mind science communication mediates reconciliation between non-science and science worlds. Some believe that teaching science only requires pedagogical content knowledge and others believe doing science requires knowledge of the methodologies of scientific inquiry. The common ground between these two is science communication which is an effective way to attain science literacy. Science communication is the key to the real treasure of scientific knowledge and scientific temper, only by which the benefits of science could be carried to the common man, and thus the common man is benefited with the new advancements in various fields of science and technology and develop scientific temper to contribute to mitigate effects of depleting resources of earth, climate change, poverty, diseases, drought, social evils etc.( DeBoer, 2000, pp. 582-601)

\section{Scientific Temper}

One of the important objective of science communication and popularization in India has been inculcation of scientific temper among masses. Merely acquiring scientific knowledge does not imply to have scientific temper. A scientifically qualified person may lack scientific 
temper; while as a contrast, even one who has not been a science student can possess scientific temper. There are enough examples of even scientists indulging in acts which can be termed as superstitious. Scientific temper has nothing to do with science but with method of science and process of scientific enterprise. It is an attitude or mental construct to look at things with reasons or methodology to follow. Scientific temper reflects one's logical, rational and analytical thinking, systematic and orderly way of his performance in all spheres of life, his reasonable behaviour and conduct in the society and of course a rational decision making power. The scientific temper and method of science portray one's overall ways of doing things or decision making. The concept of scientific temper is well-known in India. Developing scientific temper is enshrined in the Fundamental Duties Article [51-A(h)] of the Constitution of India and hence is the responsibility of each citizen of the country to possess it. Successive science policies have stressed on the dissemination of scientific knowledge and inculcation of scientific temper in society. S\&T departments and institutions or laboratories have a social mandate for science popularization and development of scientific temper among the masses. Today, science communication is a fast-emerging field of scientific enterprise both in the developed and developing countries. It is to be regarded like corporate communication for private enterprises(Raza, Dutt and Singh, 1991, pp.5-9).

In India, Vigyan Mandir experiment was one of the earliest mass scientific literacy effort. The Vigyan Mandir experiment began as the initiative of Dr S. S. Bhatnagar, then Head of Council of Scientific and Industrial Research in 1953. The first Vigyan Mandir was set up at Kapashera near Delhi, under the aegis of CSIR, on August 15, 1953 with then Prime Minster Pt. Nehru inaugurating the center. The Vigyan Mandirs were to "disseminate scientific information of interest to the rural population" and were equipped with scientific appliances, films, slide projectors and a library of books. The center was envisaged to "help and advice villagers on matters vitally concerning their well-being and to educate them on methods of science which would enable them to take greater advantage of the programmes in agriculture, health, sanitation, etc." A small rural science museum containing specimens of local flora and fauna, minerals, diseased plants, and other objects of scientific interest was to be appended to each of these Vigyan Mandirs along with scientific models demonstrating \& explaining various scientific principles. A rural science club, open to all the people living in the locality was to be organised as an activity of the Vigyan Mandir. The club was envisaged to arrange film shows on subjects connected with health, hygiene, sanitation, agriculture, popular science, village industries, etc. The Vigyan Mandir was also to serve as a platform for discussions and debates between the experts and the rural people on matters connected to the above problems. Later Indian Agricultural Reaerch Institute (ICAR) started a concept of Krishi Vigyan Kendra to disseminate information to farmers on best scientific practices in agriculture. Then came Gyan-Darshan on AIR for similar purpose of disseminating science to diverse Indian population through radio(Venkateswaran).

\section{History of Science Communication}

Public engagement with science may seem like a modern preoccupation, but its roots run deep. Science has always needed a public. From the early days of the Royal Society, when it was considered important that gentlemen should witness the conduct of experiments, up to the present when science dialogue is all the rage, the public have been in science's frame.

Second World War had a profound impact on science activities and on public's perception of science. Until, before the war, individuals or small groups who worked in universities or laboratories constituted the scientific community. Though funds 
required by them were not large, it could be easily accessed and the general perception was that funds for scientists could not be a limitation for whatever activities they wanted to carry out. Individual scientists and groups competed with each other to explore new vistas, to validate or reject the finding of their predecessors and contemporaries and contribute to the pool of knowledge. The objective was to produce scientific knowledge. By and large the produce of their labour was consumed within the community for further explorations. Results of applied and industrial research when offered to production units gave researchers some money for furthering their research. In all this the public came in only as a passive acceptor of the manufactured product. In this ethos, even what is now categorized as popularization-of-science, in nineteenth and early twentieth century was confined to serious intellectual and academic endeavour, the 'public' lectures delivered at the royal society, though open to all, were largely attended by the privileged few. The Manhattan project leading to the development of atomic bomb was an irrevocable transition in the history of science. It gave birth to what consequently came to be known as 'Big Science'. The subsequent dropping of atomic bombs at Hiroshima and Nagasaki triggered critical questioning of science and its consequences. The public, including scientists, became acutely aware of the possible negative consequences of scientific research. Information about destruction caused by atomic bomb spread rapidly and the public reaction was so intense that the emergence of peace and nuclear disarmament groups was inevitable. The impact of science and technology on development became a public issue. It was argued what science and related activities should be carried out could no longer be decided solely on the basis of the desires of the "laboratory dwellers with acid-yellow fingers and rimmed spectacles'. Developments in science and technology started finding expression in debates in public forums and in protest rallies. After the end of Second World War, massive campaigns for revamping science education and research system were launched by the Governments in United States of America and European countries. Funds were mobilized for high profile and high expenditure research projects. Consequently the government bodies and/or political formations had to communicate science to the public not simply for creating an 'enlightened public' but more so to justify to the public their own decisions of providing hefty portions of national budget to science education and research. The opening years of second half of the twentieth century saw organized efforts to popularize science through various channels. However, the Second World War and development of nuclear bomb and environment of technology competitiveness had a direct and strong impact on science communication activities. Earlier the scientists played a passive role in science communication but after the War the scientists seeking funds from military, government or industry had to justify the expenditure and in the process had to communicate science to nonexperts. Governments had to communicate science to seek public support for increased funding for science education and research. Science \& Technology had to be glorified with awe to seek support and funding for research, public debates became increasingly scientific and technical in nature. Peace movement and subsequently environmental organizations had to communicate scientific information, data and tenets to the citizens for garnering public support and enlarging their mass base. Increasing rate of technological obsolescence of production processes required continuous technical training of workers. The spread of electrically operated consumer products called for some technical understanding among the user of products. Thus there was a need to create an atmosphere where all categories of citizens could understand and accept new technical information embedded in processes and products. In other words a common citizen had to be "scientifically literate". In short, the objective of government, industry, business, as also of those critical of 
science and technology converged, though for different and sometimes even divergent reasons, to take science to the public. Science communication had emerged as a distinct and well-recognized activity (Raza).

In India, the first popular movements for science communication began in 1947, the year India obtained its independence. Several science communication activities were promoted using various channels of communication and an intensive period of publishing and translation of school and popular science books began. At the same time, small local groups of science writers and people involved in activities for the diffusion of scientific culture began to form (Salwi,).

Many Indian science writers like Jagjit Singh, Amalendu Dasgupta, Dilip M. Salwi, Harish Aggarwal, Ramesh Dutt Sharma, Gunakar Muley, Samarjit Kar, Amit Chakraborti, Pathik Guha, Niranjan Ghate, Bal Phondke, G.N. Mahapatra, D.C.Goswami, M. Nalini Mohan Rao, Lakshmi Shankar Mishra, Shankar Balakrishna Dikshit, Ramendrasundar Trivedi etc were the pioneers in writing science in their respective languages, namely, Hindi, Marathi, Bengali and Malayalam. In early 1818, popular science writing in Hindi was started in the bilingual (English-Hindi) Digdarshan published in Shreerampur, West Bengal, which was published by an Englishman Clarke Marshman. In 1842, a Bengali magazine Vidyadarshan published a series of articles on science. Subsequently, regional magazines like Marathi Dnyan Prasarak, Tamil Janavinothini, Telegu Chinthamani, Assamese Arunodoi Sambad Patra etc.were the pioneers in publishing from time to time news, articles and features on science.

Science writing began in an organised way in English in 1964 when the Council of Scientific and Industrial Research (CSIR), New Delhi, brought out a monthly magazine devoted to science called Science Reporter. Earlier in 1952, a popular science monthly in Hindi Vigyan
Pragati had also been launched. Shortly in 1966, the Times of India, Mumbai, published another popular science magazine Science Today. Later, in 1971, NRDC also launched Avishkar, a Hindi popular science monthly. The Nehru Centre, Mumbai also launched popular science magazine "Science Age'.

Kerala Shashtra Sahitya Parishad (KSSP) was formed in 1962 as a Forum of Science Writers. KSSP was confined to the language of Malayalam (a south Indian Language), while SWAI, mostly in Hindi and English. In 1966, half a dozen other organisations came into existence in Bombay (now Mumbai), initiated mainly by scientists from Bhabha Atomic Research Centre (BARC) and Tata Institute of Fundamental Research (TIFR). These organisations were also networked into a Federation of Indian Languages Science Association (FILSA) in the same year. It was founded by M. P. Parameswaran (popularly known as MP) and his associates. Initially through the efforts of FILSA, science popularisation stated in various Indian languages. These languages were Malayalam, Tamil, Kannada, Telugu, Hindi, Gujarati and Marathi. But FILSA was active only for two years i.e. from 1966-1968. The headquarters of FILSA was in BARC, Bombay. FILSA was the pre-formation of the present All India People's Science Network (AIPSN) (Kannan, 1979, pp.311-314).

As a part of KSSP's activities, several publications were brought out in order to popularise science in Kerala keeping with objectives of science for the development of society in Kerala. In 1973, the KSSP adopted the theme 'Science for Social Revolution' and took up specific issues for intensive mobilisation. Till 1978, KSSP was situating all the dissemination of science activities under the very term 'science popularisation' only.

In the Nineteen Sixties, the KSSP devised a new way of involving the masses: Science Jathtās. The Jathtās were small groups of artists, 
scientists, teachers, students and unemployed youths, travelling from village to village in a kind of procession, staging proper theatre shows at every stop, accompanied by songs and puppet shows, supported by the distribution of explanatory leaflets. These Jațtās quickly became events that village inhabitants looked forward to, and for which they regularly organised a welcome. Particular political ideology groups were largely seen associated with such movements. As such science communication was also regarded as a tool for developing public contact.

Along with the KSSP, 26 other likeminded organisations came together during the same year on the eve of the third anniversary of the Bhopal Gas Tragedy in October-November 1987 to organise the Bharat Jan Vigyan Jathā (All India People's Science Festival/People's Science Procession of India) which was sponsored by Department of Science and Technology (DST), Government of India (GOI). The Jathtā covered 500 centres in 14 states of India. Five Jathtās, along with cultural or kalā (art) groups from five different regions of the country, gathered in Bhopal, a central location in India. A 2,000 km procession converged at Bhopal from five different directions. The message was - science for peace, humanity, secularism and self-reliance. This was a massive initiative to give a fillip to science communication and promote scientific awareness through a cultural caravan.

The success of Bharat Jan Vigyan Jathā BJVJ) was followed by the first All India People's Science Conference, which was held in Kannur in Kerala in 1988. At this conference, All India People's Science Network AIPSN, a loose coalition of people's science organisations across the country, was formed.

The KSSP had been organising such Jathtās since 1980 with the involvement of local artists. The 1985 jath $\bar{a}$ was followed by similar programmes in Tamil Nadu Science Forum (TNSF) and the Pondichery Science Forum (PSF), and in the state of Gujarat with the assistance of the Gujarat Vigyan Sabha (Gujarat Science Assembly). In 1989, the KSSP undertook a massive literacy drive in the district of Ernakulam in collaboration with the district administration. The KSSP made use of its well-honed medium of kala jatha to reach out to a large population.

The very idea of kalājathā for science communication began to evolve through KSSP initiative in 1977 while organising a science cultural caravan. The first kaläjath $\bar{a}$ was launched in 1981 and still the people's science movements in India consider it as an effective method to reach out to common masses (Narayan, 1999). The kalajjath $\bar{a}$ concept of science communication developed in 1977-88. It consisted of displays of posters, banners, hoardings, stickers; pady ātrās (marching on foot), street theatres and songs. The kalājathā, a powerful medium, packs its messages in the popular cultural idioms and forms, its message was hard hitting, linking literacy with many basic livelihood problems and even with questions of exploitation, oppression and discrimination against women. They could attract audience and convey messages in an entertaining and emotionally inspiring manner. Importantly, cultural events create a forum for meeting, discussion and planning. The experience of the kalajatha indicates that traditional cultural forms generate the requisite social energy for a mass mobilisation like the literacy campaigns. The messages and the cultural forms that were utilised demonstrated a healthy combination of centralised initiative together with decentralised creativity through adaptations (Singhal, 2004).

\section{Role of RAdio}

The All India Radio was born in 1936 but a systematic effort to include science news, features, reports and interviews of scientists in radio broadcasts was made in 1975 when science cells were set up in some radio stations like New Delhi, Mumbai, Kolkata, Chennai, Bangalore 
etc. Those cells produced programmes on science in various regional languages, namely, Hindi, Marathi, Bengali, Kannada, Tamil etc. In the late 80 s and 90s two long radio serials were initiated by National Council for Science and Technology Communication, New Delhi, and the Central Education and Planning Unit of AIR, New Delhi. One of the programme was 13 episode Vigyān Vidhi, which was on method of science and its implications in daily life and programme was 144-episode-The Human Evolution, which traced the origin, history and development of man through the ages. Vigyān Vidhi and The Human Evolution were broadcast in Hindi and other regional languages during 1992-93 respectively. Special efforts were made during the broadcast to attract school children in the age group of 10-14 by announcing competitions and giving away kits and posters. Similar efforts were also made by various stations from time to time in their own regional languages considering the local need and aspirations. For example, AIT, Bangalore, produced 13 episodes Nisarga sampad $\bar{a}$ (Social forestry and nature education) series in collaboration with Karnataka Forest Department; another 13 episode serial on the human heart was produced in collaboration with the Cardiological society of India. These serials drew considerable response from masses and the demand for their audio cassettes was enormous. AIR tried a novel experiment when a 'radio bridge' was created to give an on-the-spot running commentary on the 'Total Solar Eclipse' in October, 24, 1995. Radio commentators gave a running commentary on the eclipse as well as its scientific aspects. Similarly AIR Bangalore, produced a radio programme on the Comet Hayakutake when it was sighted in March 1996. AIR, Bangalore also produced a live sky observation programme which engaged the listeners drawing them out of their house in the evening to watch a sky. "Science-phone-in" programmes was another initiative of where listeners are invited to ask questions on phone which are answered in the same programme by an expert in the field. Vigyān Prasār also sponsored a few serials of radio programmes, namely, Choo Mantar, Paryavaran Calling etc in Hindi, Bengali and Assamese.

\section{Role of Television}

Doordarshan, the national television service of India, devoted to public service broadcasting is one of the largest television networks in the world. Since its inception in 1957, Doordarshan started telecasting science programmes for students. First popular science programme telecast was 'Vigyān Partrikā' during 1971 to 1975 which was in 'Black' and 'White'. In the year 1966 broadcast of agriculture based programmes had started. From 1982, 15 August colored television had started in India and brings a new ray in broadcasting. After that during 1984-92, a popular programme based on live experiments named 'Quest' produced jointly by National Council of Science Museums and Calcutta Doordarshan, ran for eight years. A programme on the theme growth of science in India was produced by NCSTC named 'Bhärat $K \bar{l} C h h \bar{a} p$ ' and 'Bigyān kī Bāte' were broadcast in every Saturday. Then 'Turning Point' was landmark programme that started in1991. It was telecast in some regional languages also. Doordarshan also telecasted some western Television programmes on science. Many private TV channels such as National Geography, Animal Planet, and Discovery have taken up telecast of science programmes very seriously and after the emergence of these private channels, watching of programmes on science and technology has become interesting for common people. Vigyan Prasar's (VP) programme 'Science on Television' has emerged as one of its major activities. The objective is to develop and telecast science programmes on different aspects of science and technology in different Indian languages to demystify science and inculcate scientific temper. Majority of people today, receive 
substantial science and technology knowledge through television and new electronic media.

\section{Role of Newspapers}

A science-trained India-born Gobind Behari Lal went to the United States and established himself as a science correspondent of a US newspaper. In 1937, he even won the coveted Pulitzer Prize for his contributions to science journalism. Subsequently, Amalendu Dasgupta, Harish Aggarwal, W.S.Titus, T.P.Prabhu, etc, as they were working in various Indian newspapers and wrote on scientific developments in the country. Science was however just one of their beats and not an exclusive occupation. Eventually, Dr. K.S.Jayaraman, Anil Agarwal and Dr. R.Ramachandran joined as exclusive science correspondents in the Indian newspapers. In fact, the Press Trust of India started a separate science cell under the leadership of Dr. Jayaraman, which continues to supply features and stories on science to the Indian press even today. Thereafter scientific developments in India began to appear more frequently in the columns of newspapers and magazines. There was a phase in the late $80 \mathrm{~s}$ and early 90 s when some major newspapers also started publishing regular supplements on science. Hindi leads in this endeavour. It appeared as though science had at last caught on in the Indian press (Pataria; Raza, Dutt and Singh, 1991).

\section{Role of Scientists}

Eminent Indian scientists like Mahendralal Sircar, J.C. Bose, P.C. Ray, Ruchi Ram Sahni and others carried the tradition of science communication forward in Kolkata and Punjab enlightening the Indian masses on the latest and exciting developments in science. After the Independence, Meghnad Saha, S.N. Bose, C.V. Raman, D.S. Kothari and others were closely associated with science popularisation and spread it to other parts of the country. Particularly, the great physicist S.N.Bose was keen on bringing science to masses in their mother tongue. He urged Indian scientists to speak and write about science in their mother tongues. In 1948 he went on to found an association and even a magazine to popularise science among Bengalis.

Meghnad Saha was one of the pioneers of modern physics in India. Saha's theory of thermal ionisation and its application in the solar and stellar spectra opened a new direction in astrophysics. The U.P. Academy of Sciences, Allahabad (later named National Academy of Sciences of India, Allahabad) was set up by Saha and the objective was to collect the scientists in one forum. He had invited Jawaharlal Nehru and Subhas Chandra Bose to address the conferences organised by the Academy to discuss national problems. As General President of the Indian Science Congress in 1934, he pleaded for an All India Academy of Sciences. The General Body of the Science Congress Association agreed and formed a large committee representing scientists from all branches in the universities, institutes and government survey departments, the Asiatic Society of Bengal, etc. and the National Institute of Science was formed (This was later renamed as Indian National Science Academy and the headquarters shifted from Calcutta to New Delhi). In 1935, he started the journal 'Science \& Culture' for popularisation of science. Professor Bidhu Bhusan Roy from Calcutta became its co-editor. Later, when Indian Science News Association was formed in Calcutta, Science \& Culture became its organ. For 20 years, Science and Culture devoted itself to its two fundamental objectives: the interpretation of science and its popularisation, and an advocacy of the full scale application of science to bring about a technological revolution (Bose, 1967) .

Ruchi Ram Sahni was a pioneer educationist who popularised and spread the knowledge of science by means of popular science lectures with lantern slides and actual demonstrations in remote parts of Punjab (Fig.1). Ruchi Ram started 
his popular science lecture series in 1886 while being posted at Simla, and the theme was weather forecasting. His popular science lectures, under the aegis of Punjab Science Institute (PSI), set up in 1885 and those days Punjab was extended from Delhi to Peshwar and included present day Haryana, Himachal Pradesh and the Pakistani Punjab. These lectures became a great hit with common people. Village and urban folk, labourers and shopkeepers flocked to them, often buying a two-anna (anna is sixteenth of a rupee) 'ticket' to witness the performance! These lectures created so much enthusiasm and interest in the study of science that by the end of nineteenth century, the

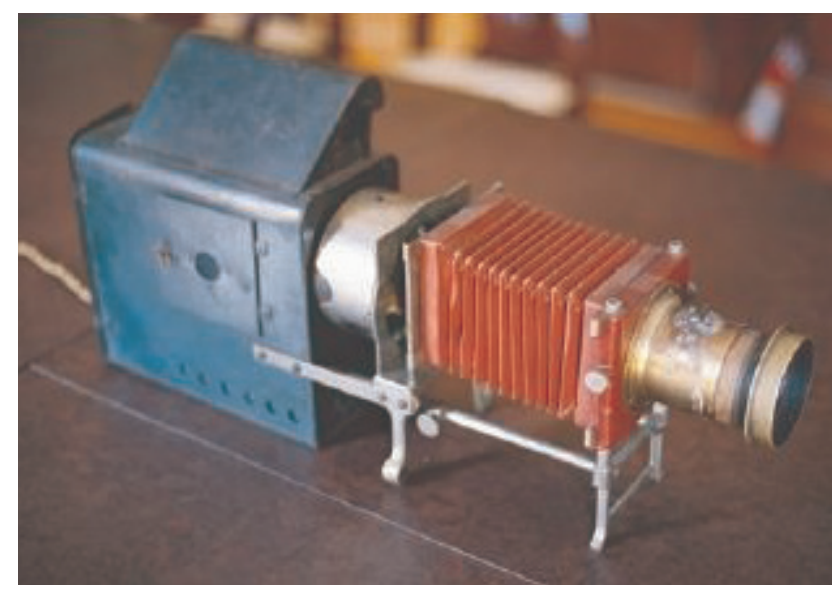

Fig.1. Early model of a Magic Lantern Slide Projector and methods used by Ruchi Ram Sahni to make slides.

number of schools teaching elementary physics and chemistry in Punjab was more than in any other province in India (Sehgal and Mohanti).

\section{Role of Institutions}

Systematic approach to science communication was started by establishing national institutes \& organisations, notably the National Council of Science Museums (NCSM), National Council of S\&T Communication, Vigyān Prasār \& units set up in Sate Councils of Science and Technology. The National Council for Science \&Technology Communication under
Department of Science \& Technology (DST), was specifically launched in 1982 to promote science communication in the country. One notable achievement of the organisation was the utilisation of various media, both traditional and modern for promotion of science and technology. In 1989, Vigyān Prasār (an autonomous organisation of the Department of Science and Technology) was setup. The National Institute of Science, Communication, and Information Resources (NISCAIR) came into existence in September 2002 with the merger of National Institute of Science Communication (NISCOM) and Indian National Scientific Documentation Centre (INSDOC) with an objective to collect and store, publish and disseminate scientific and technological information through the use of modern as well as traditional media (Mochahari, 2013). On the recommendation of Task force set up by Planning Commission, a network of science museums (NCSM) to expand science museum activity in the country was set up in 1978. Since then, 48 science museums and science centres have been set up in different parts of the country including under developed areas.

\section{Science Museums \& Science Centres}

Science Museums and science centres are important institutions which not only house curios of scientific nature to enhance the scientific curiosity, literacy and awareness among the masses but also are of vital significance to assist science education programme of the country (Fig. 2.). Globally, Science centres and museums provide active inquiry-based learning and allow people, particularly the young generation, to engage with and experience the science and technology governing the world in which they live. In a developing economy, the non-formal approach of science centres to $\mathrm{S} \& \mathrm{~T}$ education may be very effective in spreading science literacy and awareness and in hooking up the young to science, technology and mathematics (STEM). 


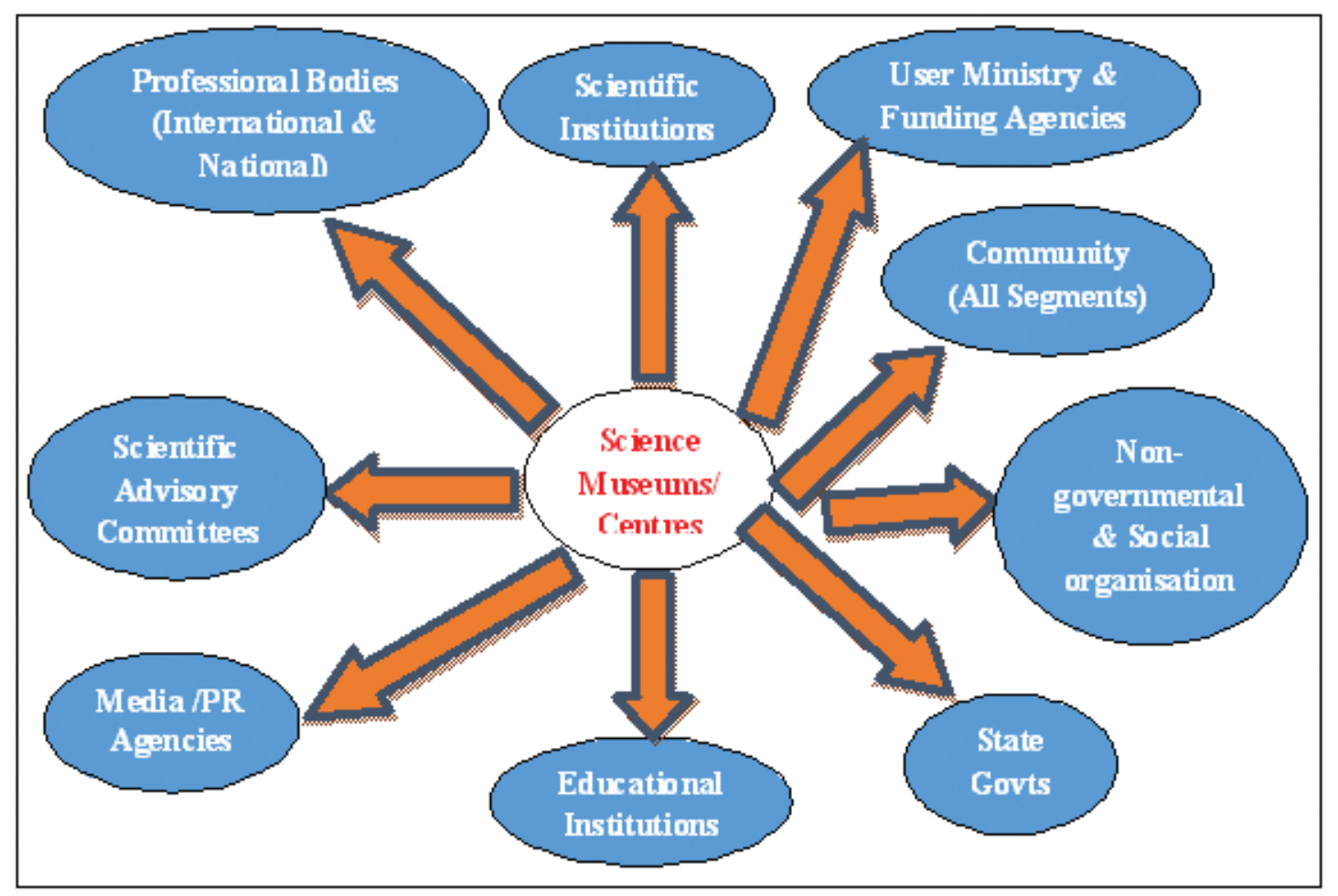

Fig.2. Operational Network of Science Centres

The strength of the non-formal mode lies in its premises of engagement, open and informal ambience, easy access and social inclusiveness and lifelong learning opportunities.

In India, the idea of communicating science through the medium of Science Museums was accelerated with the establishment of the National Council of Science Museums (NCSM) in 1978. Like the crystal palace Industrial Trade Exhibition in London gave birth to the London Science Museum, similar trade exhibition of British products and processes gave birth to Lord Reay Science Museums in cantonment area of Pune in 1892. However, the development of the science museum as an activity was started in 1953, when the Birlas set up the first science museum in Pilani. Later organized science centre activity of the government started in India in May 1959 when the first science museum, Birla
Industrial and Technological Museum (BITM) started functioning in Calcutta. Following the success of this museum, Council of Scientific and Industrial Research (CSIR), the then body under which the science museums were functioning, was offered another place by the Sir Visvesvaraya Industrial Museum Trust in Bangalore to start a science museum and thus the second science museum in Bangalore, Visvesvaraya Industrial and Technological Museum (VITM), named after legendary engineer Sir Visvesvaraya, started functioning in July 1965. Later the first Science Centre based on participatory approach was built in Mumbai in 1978.

In line with the recommendations of Task Force, the Government of India decided to delink the three science museums BITM, VITM and Nehru Science Centre, Mumbai from CSIR 
and put them under a newly formed autonomous body, the National Council of Science Museums (NCSM) in 1978. The new Society (NCSM) which came into being on 4th April 1978, was attached to the Ministry of Education and Social Welfare as the user Ministry. The priorities given to the

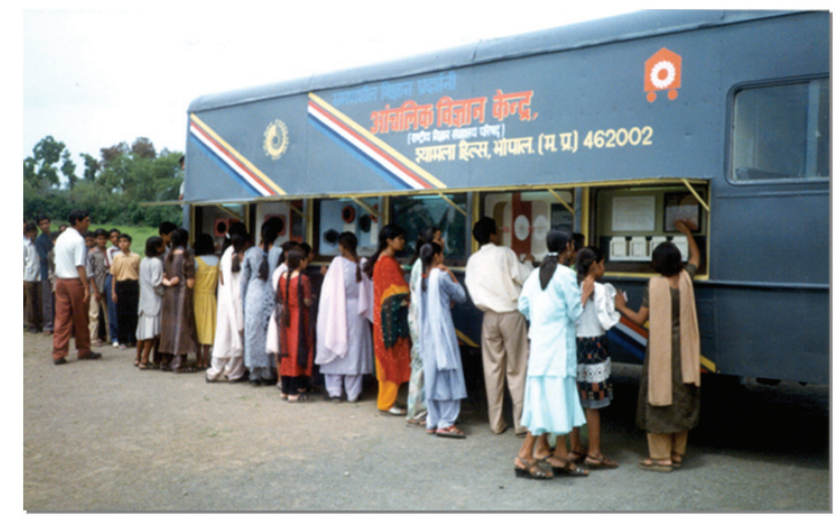

Fig.3. NCSM operates 23 Museo-buses all over the country.

NCSM was to operate and maintain the existing three science museums and develop new science centres in the country for the benefit of the society. Later in 1979, the name of the Ministry was changed to the Ministry of Education and Culture. Presently the Council is attached to the Ministry of Culture. Over the last three decades, NCSM has set up a large network of 48 Science Museums and Science Centres in the country (Fig. 3.). This is the largest formal network in the world.

The annual footfall to 25 centres under the administrative control of NCSM has reached 12.5 million. The year round activities for community, teachers, and students engage them in the process of science, discovery and debates for greater appreciation and understanding of concepts \& issues in S\&T.

In order to reach out to public in remote areas of the country with simple programs, the idea of Mobile Science Exhibits (MSE) was conceived in 1965. In order to communicate universal science concepts to those who could not or have access to museums, the Museobus was introduced.
Currently 23 such mobile units are functioning out of science centres especially in remote areas \& reach out to over 2 million rural students, teachers and public every year.

\section{Science on Wheels: A National Festival}

The year 2004 was declared as the year of Scientific Awareness. Another significance of that year was the happening of a mega event"Science on Wheels: A National Festival" in the history of Mobile Science Exhibition. The event was organised at Regional Science Centre, Nagpur during 24-28 December 2014 where 14 Mobile Science Exhibition units from different parts of country covered thousands kilometres with the message of science and technology finally exhibited at Raman Science Centre, Nagpur. The festivals included a series of science activities, workshops, demonstrations, lectures, science dramas, science film shows and several other programmes. The exhibition themes of the mobile science van were diverse in nature and touched upon different scientific and technological subjects like water, environment, time, perception, invention, food and nutrition, forest, fun science popular science, space and mankind etc. relevant to society. Truly it connected the rural areas of the country in one single attempt. The message reached to millions through out the country all at once.

All NCSM galleries and outreach programs incorporate interactive mode of communicating science (Fig. 4.). The excellence in production of state-of-the-art exhibits, travelling exhibitions on contemporary issues related to S\&T, new communication methods, innovative display techniques, interactive and experience-based exhibits/learning aids has created an ever increasing demand for new science centres (Fig. 5.). It is expected that this network will grow to 66 at the end of 12 th plan. 


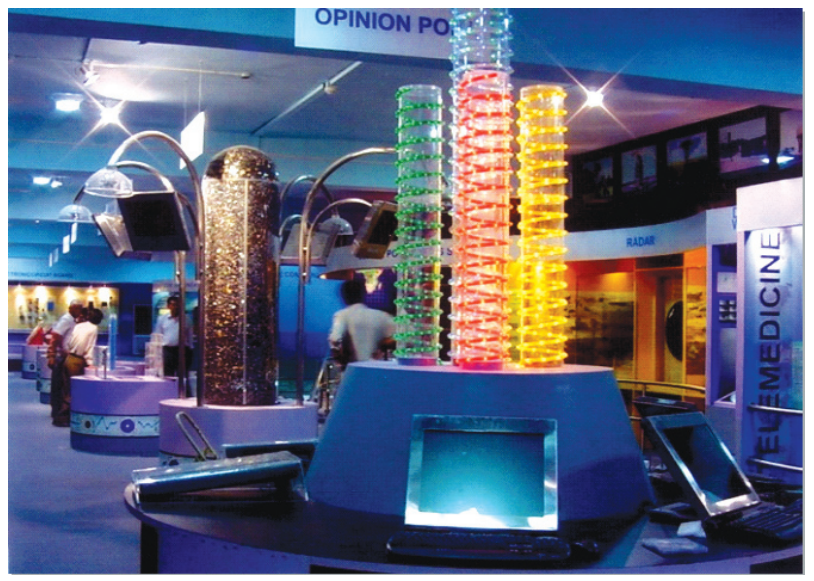

Fig. 4. View of gallery in a science centre
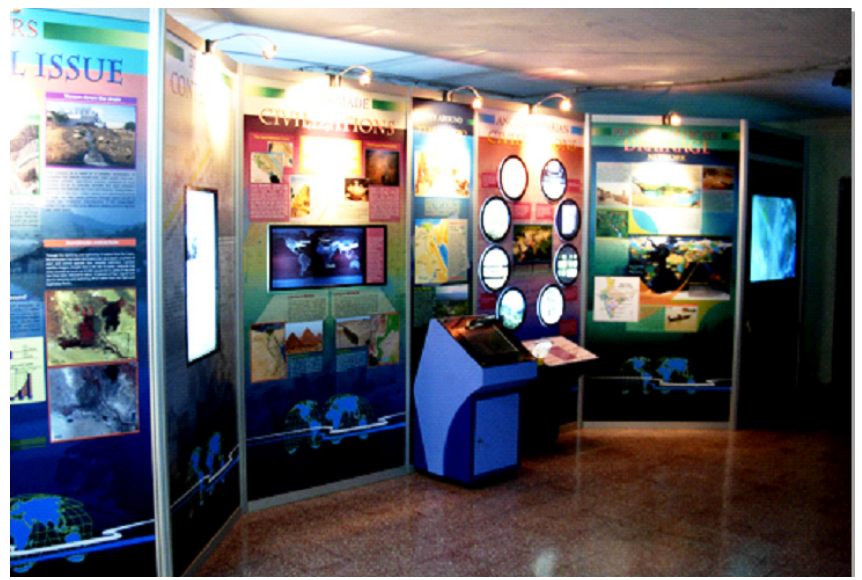

Fig. 5. View of travelling exhibitions on the contemporary issues of S\&T

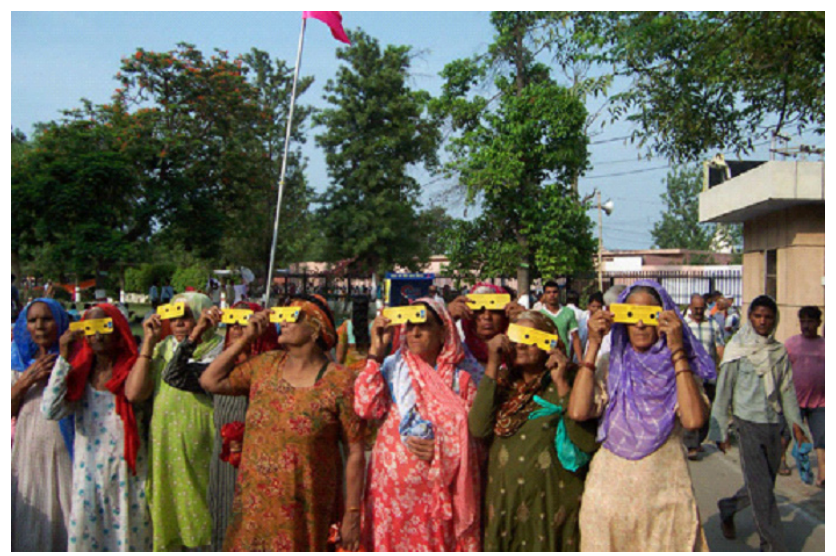

Fig. 6. Solar Eclipse programme for rural people,

\section{Impact of Science Museums \& Science Centres}

Science Centres provide a significant range of educational, social, cultural and economic benefits to their communities and various studies on the impact of science centres and the assessment of the extent of the influence of the scientific knowledge implicated by the society have indicated positive outcomes. There are several false beliefs prevalent in our society regarding solar eclipse. Some people even lock themselves up in their homes to avoid 'the bad rays 'from the eclipse. Many also take a dip in holy rivers to cleanse themselves after the eclipse and some avoid cooking and eating during the eclipse. During the period of eclipse Science Centres and
Science Museums in India make arrangements for viewing the event to dispel the myths and superstitions and to create a scientific temper among the visitors (Fig.6.).

A number of studies in several countries have revealed that informal exposure to science, comprising visit to science centres, has a major influence in career choice. In India several successful scientists attribute their career choice to their visit to science museums and centres in formative stage of their educational path. A glimpse in the visitors' book of any science centre will reveal that generations of scientists attributed their lifelong interest in science to the childhood visit to Science Museums. 
Science Centres particularly the small centres situated in remote and backward areas, have a long tradition of providing vocational training to the local unemployed people, which could help them start small enterprises and earn

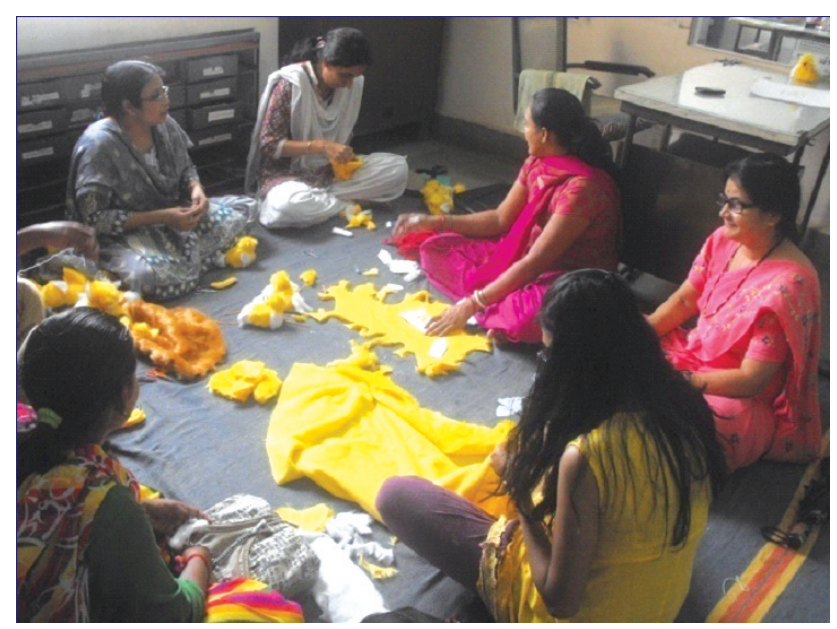

Fig. 7. Soft Toy making workshop for women

a decent living. In many such cases in India, the Science Centres acted as catalysts of technology transfer from laboratories and industries to the local community (Fig.7.).

The Science Centres are not only involved in creating public awareness of science but they also carry out national as well as international educational programmes such as International Astronomy Olympiads, National Science Dramas, National Science Seminar for students that have a tangible outcome.

The science centres focus on generating pride in their region for local residents, resulting from the success and reputation of the science centre. Local community takes pride in facilitating or recommending visit to science centres for their guests and relatives and accompany them which enhance social interaction and values. In India, Science City, Kolkata has become an iconic place of pride both for local community and government and a sustainable institution which generates its own funds to run.
Science Centres often get neglected plots of land having no demand. However, once the Science Centres are built and lush greenery of Science Parks develop, an environmental restoration and up-gradation takes place. Two glaring examples from India are Nehru Science Centre, Mumbai and Science City, Kolkata which were built on garbage dumping grounds. This development enhances the realestate value and importance of the locality.

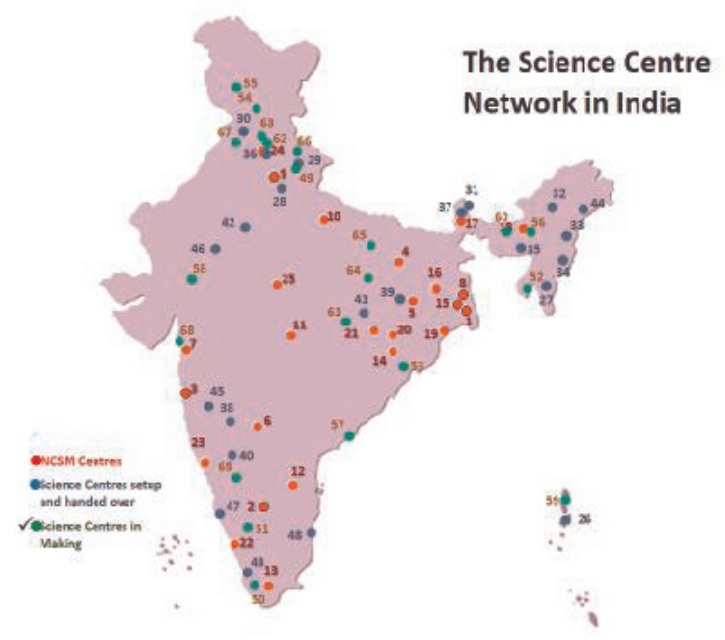

Fig. 8. Expected network of Indian Science Museums / Centres in 2017

After thirty six years of existence NCSM has 25 units under its control and the Council has developed 23 more science centres for various state governments and other institutions and 18 more are in making (Fig.8.). In addition NCSM has provided catalytic support to many Science Centres in India and abroad (Rautela and Sanyal, 2010).

\section{Conclusion}

Science and technology underpin our economy, our ability to support our growing population, and new developments to keep us healthy. Without scientific literacy, both in today's adult population and in generations to come, our nation stands to lose its ability to compete on a global scale. The future of our youth depends on 
their fluency in science in a world where employers seek well-educated, well-aware individuals.Our leaders need reasoned decision making. Even our own ability to survive as a species depends on understanding the threats to our ecosystems and the choices we can make to mitigate these threats. India has been a knowledge economy and has a tradition in science and technology from the ancient times. India now needs policies and programs to reclaim its global leadership position in science and technology. Science and technology has enormous potential to bridge the disparities between the urban and rural India, rich and poor. Science education needs to be made more practical, meaningful with renewed vision and vigour. It needs to be balanced with tutorials, practical \& non-formal engaging activities. Science needs to be communicated in an innovative way with a focus on engagement which shall enable todays' and tomorrows' citizens to play a more active role in the research and innovation process, to make informed choices and to build a democratic and knowledge-based society. This approach will lead young boys and girls to pursue careers in science, technology, engineering and mathematics $\&$ make worthwhile contributions in knowledge creation and innovation. A nation of 1200 million, India needs a focussed and large scale science communication strategy if we have to develop into a scientifically \& technologically literate society. Present initiatives \& efforts are miniscule $\&$ need scaling up.

\section{BiBLIOGRAPHY}

Ahmed, A. and Stein, J. A. Science, Technology and Sustainable Development: A World Review. World Review of Science Technology and Sustainable Development, 1(2004):5-24.

Bose, D M. Meghnad Saha Memeorial Lecture, Science and Culture, Bose Institute 33 A. 3 \& 4, 1967

Burns, T. W.; O'Connor, D. J. And Stocklmayer, S. M. Science Communication: A Contemporary Definition. Public Understanding of Science, 12(2003): 183-202.
DeBoer, George E. Scientific Literacy: Another Look at Its Historical and Contemporary Meanings and its Relationship to Science Education Reform-, Journal of Research in Science Teaching, 37. 6(2000): 582- 601 .

Holbrook, Jack and Rannikmae, Miia. The Meaning of Scientific Literacy-, International Journal of Environmental \& Science Education, 4.3 (2009): 275-288.

Kannan, K P. Towards a People's Science Movement, KSSP, Calicut. - (1990): 'Secularism and People's Science Movement in India', Economic and Political Weekly, 28.5(1979): 311-14.

Libutti, L. and Valente, A. Science Communication and Information Dissemination: The Role of the Information Professional in the Perception and Awareness of Science' Project. Journal of Information Science, 32(2006): 191-197.

Martinez, E. Boosting Public Understanding of Science and Technology in Developing Countries. Paper presented at World Conference on Science, 1999.

Miller, J. D. Public Understanding of, and Attitudes Toward, Scientific Research: What We Know and What We Need to Know. Public Understanding of Science, 13(2004): 273-294.

Miller, J. D., Pardo, R. and Niwa, F. Public Attitudes Toward Science and Technology: A Comparative Study of the European Union, the United States, Japan, and Canada, BBV Foundation, Madrid, 1997.

Monjib Mochahari, Revisiting India's Science Communication and Journalism: Issues and Challenges, Article 7, Global Media Journal - Indian Edition/ISSN 22495835, Sponsored by the University of Calcutta/ www. caluniv.ac.in, Summer Issue / June 2013/ Vol.4/ No.1.

Patairiya, Manoj. Science Communication in India: Perspectives and Challenges-, SciDev.Net 03/20/2002.

Norris, S.P., \& Phillips, L.M., How literacy in its fundamental sense is central to scientific literacy, Science Education, 87 (2003):224-240.

Rautela G S and Sanyal I. Impact of Science Museums and Centres- Propagation, Vol.1, No. 1, 2010.

Raza G., Dutt B., Singh S,. Scientific Attitude Among Masses, A Report of the Survey Conducted at Allahabad during Kumbh Mela in 1989, Vol.I, NISTADS-REP-107(AV) 91), 1991, pp. 5-9. 
Raza, Gauhar, Public Understanding of Science

Rennie and Williams, G.F. Science centres and scientific literacy: Promoting a relationship with science, Science Education, 86(2002): 706-726.

Rogers, E. M. Communication and Development: The Passing of the Dominant Paradigm. Communication Research, 3(1976): 213-240.

Salwi, Dilip M. Science in India Media-a Blueprint for New Millennium, Vigyan Prasar, Delhi.

Science, Technology and Innovation Policy 2013, Ministry of Science \& Technology Government of India.

Science in India, 2004-2013, Decade of Achievements and rising Aspirations, Science Advisory Council to the Prime Minister, Department of $S \& T$ Government of India.
Sehgal, Narender K., Mahanti, Subodh. Memoirs of Ruchi Ram Sahni: Pioneer of Science Popularisation in Punjab.

Simon, J. Circumventing the "Elusive Quarries" of Popular Science: The Communication and Appropriation of Ganot's Physics in Nineteenth Century Britain. In: Popularizing Science and Technology in the European Periphery, 1800-2000. (eds., Papanelopoulou, F., Nieto-Galan, A. and Perdiguero, E.), Ashgate Publishing Ltd., England, 2009pp. 89-114.

Singhal, Vineeta. Public Understanding of Science: Issues are many! Indian Journal of Science Communication, 3.2, July-Dec, 2004.

Venkateswaran, T. V . Vigyan Mandir Experiment The First Mass Scientific Literacy Effort in India, Proceedings of epiSTEME 5, India. 